\title{
Mice Doubly Deficient in the Genes for P0 and Myelin Basic Protein Show That Both Proteins Contribute to the Formation of the Major Dense Line in Peripheral Nerve Myelin
}

\author{
Rudolf Martini, M. Hasan Mohajeri, Simone Kasper, K. Peter Giese, ${ }^{a}$ and Melitta Schachner \\ Department of Neurobiology, Swiss Federal Institute of Technology, Hönggerberg, $\mathrm{CH}-8093$ Zürich, Switzerland
}

\begin{abstract}
In search for the molecular mechanisms underlying the formation of the major dense line in peripheral nerve myelin we investigated mice deficient in the myelin proteins P0 and MBP. In mice lacking both molecules axons were enwrapped by myelin-like processes devoid of the major dense line, while mice deficient in either protein showed, respectively, partial and normal compaction. Mice heterozygous for PO but devoid of MBP showed myelin of reduced thickness around axons of normal caliber. Both molecules thus contribute to the formation of the major dense line and to the determination of myelin thickness. Furthermore, our observations modify the view that axon caliber is dependent on normal myelin.
\end{abstract}

[Key words: double knock-out mutants, functional redundancy, glia, myelin compaction, myelin genes, Schwann cells]

An important contribution to efficient propagation of nerve impulses is the formation of myelin sheaths around larger caliber axons. Myelin sheaths are generated during ontogeny by the cellular processes of either oligodendrocytes in the central or Schwann cells in the PNS, which turn around axons in a spirallike manner. In its mature state the bulk of the myelin sheath is compacted; that is, the extracellular space between the turning loops is drastically reduced and their cytoplasm has disappeared to yield the intraperiod and major dense lines, respectively.

In the PNS, the adhesive, immunoglobulin-like molecule P0 has been suggested to mediate both the extracellular and the cytoplasmic compaction of myelin (Lemke, 1986, 1988, 1993). The extracellular domain of $\mathrm{P} 0$ most likely interconnects the turning loops of Schwann cell processes via homophilic binding mechanisms resulting in the formation of the intraperiod line (D'Urso et al., 1990; Filbin et al., 1990; Schneider-Schaulies et al., 1990). The intracellular part of P0 contains predominantly basic residues that might interact with the phospholipids of adjacent cytoplasmic aspects of Schwann cell membranes leading to the formation of the major dense line (Kirschner and Ganser, 1980; Ding and Brunden, 1994). That the molecule is, indeed, pivotal for myclin compaction was revealed in peripheral nerves

\footnotetext{
Received Oct. 17, 1994; revised Jan 10, 1995; accepted Jan 23, 1995.

We are grateful to Drs. Nicole Baumann and Françsois Lachapelle for providing us with shiverer mouse mutants, Dr. Robert Bernhardt for critical comments on the manuscript, and Kathrin Mannigel for animal care.

Correspondence should be addressed to Rudolf Martini at the above address.

Present address: Cold Spring Harbor Laboratory, Cold Spring Harbor, NY 11724.

Copyright $(1995$ Society for Neuroscience $0270-6474 / 95 / 154488-08 \$ 05.00 / 0$
}

of P0-deficient mice that are severely compromised in myelin compaction, particularly at the site of the intraperiod line (Giese et al., 1992). However, many Schwann cells still formed the major dense line (Giese et al., 1992). A candidate molecule that may substitute for $\mathrm{PO}$ in fonmation of the major dense line is the myelin basic protein (MBP), an intracellular constituent of central and peripheral myelin of wild-type and $\mathrm{P0}$-deficient mice (Lemke, 1986; Giese et al., 1992). MBP appears to be essential for the formation of the major dense line in the CNS where P0 is not expressed. This view derives from the observation that in CNS of shiverer mutant mice, which do not express MBP (Roach et al., 1983), major dense lines are missing (Privat et al., 1979; Rosenbluth, 1980b), but can be reconstituted by introducing the wild-type MBP gene into the germ line of these mice (Readhead et al., 1987). That shiverer mutant mice show no major morphological abnormalities in the PNS (Kirschner and Ganser, 1980; Rosenbluth, 1980a) has, at least in part, been attributed to the relative paucity in expression of MBP $(5-15 \%$ of all myelin proteins) and the abundance of $\mathrm{P} 0(50-60 \%$ of all myelin proteins; Kirschner and Ganser, 1980; Lemke, 1986, 1988, for reviews).

In the present study, we have investigated the possibility that both P0 and MBP are responsible for the formation of the major dense line in peripheral nerve myelin. We therefore generated mice deficient for both $\mathrm{PO}$ and MBP by cross-breeding mice deficient for one allele of each gene $\left(\mathrm{P}^{+-} / \mathrm{MBP}^{+-}\right)$. The double mutants obtained $\left(\mathrm{PO}^{--} / \mathrm{MBP}^{--}\right)$were severely hypomyelinated in peripheral nerves that contained myelin-like sheaths completely devoid of major dense lines. Furthermore, comparison of the appearance of myelin sheaths in $\mathrm{P}^{++} / \mathrm{MBP}^{--}$(shiverer), $\mathrm{P}^{+-} / \mathrm{MBP}^{++}$, and $\mathrm{P} 0^{+-} / \mathrm{MBP}^{--}$mice revealed that both $\mathrm{MBP}$ and $\mathrm{PO}$ are not only involved in myelin compaction but also determine myelin thickness.

\section{Materials and Methods}

Generation of mutants and determination of genotypes. P0 knock-out mice $\left(\mathrm{P}^{--} / \mathrm{MBP}^{++}\right)$and mice deficient for one allele of this gene $\left(\mathrm{PO}^{+-} / \mathrm{MBP}^{++}\right.$) have been taken from our own breeding colony (Giese et al., 1992). The genotypes of these mice was assessed by Southern blot analysis of genomic DNA isolated from tail clips of mice at 3 weeks of age (Giese et al., 1992).

MBP-deficient mice ( $\mathrm{PO}^{++} / \mathrm{MBP}^{--}$, shiverer) were a kind gift of Drs. N. Baumann and F. Lachapelle (Paris). The homozygous phenotype of these mice was determined by their shivering behavior and by Southern blot analysis performed as described (Giese et al., 1992) using a full length rat MBP cDNA (Roach et al., 1983; kindly provided by Dr. K.A. Nave, Heidelberg). Heterozygous mice $\left(\mathrm{PO}^{++} / \mathrm{MBP}^{+-}\right)$, which do not show any abnormal behavioral phenotype, could only be recognized by means of the geno- and phenotypes of their offspring since appropriate 
probes unequivocally distinguishing between $\mathrm{MBP}^{++}$and $\mathrm{MBP}^{+-}$genotype are not available.

To obtain double mutants, mice deficient for one allele of each gene $\left(\mathrm{PO}^{+-} / \mathrm{MBP}^{+-}\right)$have been generated by cross-breeding of $\mathrm{PO}^{+-} / \mathrm{MBP}^{++}$ and $\mathrm{PO}^{++} / \mathrm{MBP}^{+-}$mice. The use of such double heterozygous breeders had the particular advantage that not only double homozygous mutant mice $\left(\mathrm{PO}^{--\cdot} / \mathrm{MBP}^{--}\right)$, but also $\mathrm{MBP}$-deficient micc $\left(\mathrm{PO}^{++} / \mathrm{MBP}^{--}\right.$, shiverer) and mice heterozygous for $\mathrm{PO}$ and deficient for $\mathrm{MBP}\left(\mathrm{PO}^{+-}\right.$ $\mathrm{MBP}^{--}$) could be obtained in one litter. The P0 genotype of such mice was assessed by Southern blot analysis, their homozygous MBP-deficient genotype by their shivering phenotype and by Southern blot analysis. Additionally, the absence of MBP was determined by Western blot analysis of brains and sciatic nerves (Giese et al., 1992) using polyclonal antibodies to MBP (kind gift of Dr. N. Baumann, Paris). Mice with wild-type alleles for $\mathrm{MBP}\left(\mathrm{P0}^{++} / \mathrm{MBP}^{++}, \mathrm{P0}^{+-} / \mathrm{MBP}^{++}, \mathrm{PO}^{--} /\right.$ $\mathrm{MBP}^{++}$) were taken from litters originating from parents with a $\mathrm{PO}^{+-}$ $\mathrm{MBP}^{++}$genotype, since the $\mathrm{MBP}^{++}$genotypes cannot be directly distinguished from the $\mathrm{MBP}^{+-}$genotypes, either by Southern blot analysis or by their behavioral phenotypes (see above).

Electron microscopy. For electron microscopic investigations, sciatic nerves and femoral nerve branches of deeply anesthetized $(30 \mu \mathrm{l} / \mathrm{gm}$ body weight of $3 \%$ chloralhydrate), 4-week-old mice were either fixed in situ by rinsing the exposed nerves with $0.1 \mathrm{M}$ cacodylate buffer containing $2 \%$ paraformaldehyde and $2 \%$ glutaraldehyde for $20-30 \mathrm{~min}$ or by intracardial perfusion with the same fixative. The latter procedure was necessary when mice with normally compacted myelin were investigated. The nerves were excised and postfixed in the same fixative overnight. After osmification with $2 \% \mathrm{OsO}_{4}$ in the same buffer, the samples were dehydrated in acetone and embedded in Spurr's medium. For all mice with a homozygous MBP-deticient genotype, spinal cord and optic nerves were also inspected to verify the genotype.

Defermination of axon diameters and axon-fiber ratios. For quantitative analysis and to facilitate comparison of the nerves of the different genotypes, all of the about 90 myelinated axon-Schwann cell units of the pectineus nerve, a small muscle nerve branchlet of the femoral nerve, were considered (see Montag et al., 1994). In comparison to a random selection of axon-Schwann cell units in large and complex nerve trunks, this had the advantage that one is always dealing with comparable populations of axon-Schwann cell units. Axonal diameter and thickness of nerve fibers (fiber $=$ axon plus myelin, measured at the outer cytoplasmic aspect of the myclinating Schwann ecll), were determined on electron micrographs at a magnification of $7.500 \times$ using computer-assisted image analysis (IBAS). Since axons and nerve fibers are seldom round in cross-sections, their diameters were determined as axonal or nerve fiber circumference, respectively, divided by $\pi$. For the determination of axon-fiber ratio, only Schwann cells with myelin of normal compaction extending over the entire thickness of the sheath were considered. Therefore, the myelin-like sheaths of P0-deficient $\left(\mathrm{PO}^{--} / \mathrm{MBP}^{++}\right)$and double mutant mice $\left(\mathrm{PO}^{-}-\mathrm{MBP}^{--}\right)$were not included in these measurements.

Significance of differences between values from wild-type mice and the different genotypes was determined by the Mann-Whitney $U$ test using STATVIEW II software.

\section{Results}

We investigated the peripheral nerves of the following genotypes by transmission electron microscopy: $\mathrm{PO}^{++} / \mathrm{MBP}^{++}$(wild type), $\mathrm{PO}^{++} / \mathrm{MBP}^{--}$(shiverer), $\mathrm{P}^{+-} / \mathrm{MBP}^{++}, \mathrm{P}^{+-} / \mathrm{MBP}^{--}, \mathrm{PO}^{--} /$ $\mathrm{MBP}^{++}(\mathrm{P} 0$ deficient $)$, and $\mathrm{PO}^{--} / \mathrm{MBP}^{--}$(double mutant). Since mice deficient for both $\mathrm{P} 0$ and $\mathrm{MBP}\left(\mathrm{PO}^{--} / \mathrm{MBP}\right)$ only lived for 5-6 weeks, 4-week-old mice were investigated. Ultrathin cross-sections were taken from sciatic nerves (approximately 3 $\mathrm{mm}$ distal to the sciatic notch), the quadriceps muscle, and the cutaneous (saphenous) branches of the femoral nerve, and, for quantitation, from the pectineus muscle nerve, from which all approximately 90 axon-myelin units were evaluated.

In the following, the genotypes are arranged in the order of increasing severity of abnormalities.

$\mathrm{PO}^{++} / \mathrm{MBP}^{++}$(wild type), $\mathrm{PO}^{+-} / \mathrm{MBP}^{++}, \mathrm{PO}^{++} / \mathrm{MBP}^{--}$

(shiverer)

At lower magnifications, compacted myelin of wild-type mice $\left(\mathrm{PO}^{++} / \mathrm{MBP}^{++}\right)$was characterized by a high electron density, occasionally interrupted by noncompacted parts, such as the paranodal loops and Schmidt-Lanterman incisures (Fig. 1A). At higher magnifications, a very regular organization of major dense and intraperiod lines was seen (Fig. 1B). The pectineus nerve of such mice comprises about 90 myelinating axonSchwann cell units $(89 \pm 8.1)$ with axonal diameters of about $3 \mu \mathrm{m}(2.99 \pm 0.41 \mu \mathrm{m}$; Table 1$)$. The ratio of axonal and fiber diameter (fiber - axon plus myelin, as measured at the outer cytoplasmic aspect of the myelin sheath) was $0.71( \pm 0.01$; Table 1) and is thus comparable to values given in peripheral nerves of rats (Friede, 1970).

Mice deficient in one allele of $\mathrm{P} 0\left(\mathrm{PO}^{+-} / \mathrm{MBP}^{++}\right)$revealed a behavioral phenotype not distinguishable from that of wild-type mice, whereas shiverer mice $\left(\mathrm{P}^{++} / \mathrm{MBP}^{--}\right)$showed severe tremors and occasional seizures as described previously (Hogan and Greenfield, 1984). In peripheral nerves, both genotypes showed normal axon diameters and myelin sheaths (Fig. $1 C$, Table 1), with the only exception that in shiverer mice the axonfiber ratio was slightly reduced in comparison to wild-type mice $(0.66 \pm 0.02 ; p \leq 0.018$; Table 1$)$, indicating a relative increase in myelin thickness.

\section{$P 0^{+-1} / M B P$}

The behavioral phenotype of these mice was not distinguishable from that of shiverer mice $\left(\mathrm{P}^{++} / \mathrm{MBP}\right)$. The myelin sheaths of these mice were abnormal (Fig. $1 D$ ). In all nerves, normally compacted myelin was observed, but a high number of axonSchwann cell units showed more or less extended aspects of noncompacted myelin, most often at the inner, axon-related turns of the Schwann cell (Fig. $1 D$ ). In cross-sections of the pectineus nerve, more than half of all myelin sheaths $(56.7 \pm 5.6 \%)$ had such noncompacted parts, whereas in pectineus nerves of wildtype mice, only about $9 \%(8.74 \pm 4.36 \%)$ of the myelin sheaths were interrupted by either Schmidt-Lanterman incisures or paranodal loops. Those sheaths consisting of entirely compacted myelin $(43.3 \pm 4.5 \%)$ were too thin relative to the caliber of their axons (Fig. $1 D$ ), resulting in a robust elevation of axonfiber ratios $(0.81 \pm 0.02 ; p \leq 0.02$, Table 1). A small, but significant number of Schwann cells did not form myelin, but appeared to be arrested at the $1: 1$ ratio $(3.4 \pm 2.1 \%)$. Axonal calibers were normal $(2.93 \pm 0.35 \mu \mathrm{m}$; Table 1$)$. Occasionally, some macrophages were visible in the endoneurium (not shown).

\section{$\mathrm{PO}^{--} / \mathrm{MBP}^{++}$(PO deficient)}

Behaviorally, these mice show slight tremors, dragging of hindlimbs, and clasping of hindlimbs when lifted by the tail after approximately 4 weeks of age (Giese et al., 1992). Ultrastructurally, a severe hypomyelination in sciatic, femoral, and pectineus nerves with a high variability in morphology was detected (Giese et al., 1992; Fig. 2A). Since the present study focusses on the formation of the major dense line, we have quantified axon-Schwann cell units with regard to the presence or absence of this structure by assigning each unit to one of three ultrastructurally distinct groups. The first category comprises myelinlike sheaths containing a major dense line. Most often, the parts containing major dense lines formed several continuous turns at the inner, axon-related sites of the myelin-like sheaths (Fig. 2A). A typical feature was the undulating appearance of the major dense lines and the absence of intraperiod lines, resulting in slightly widened intraperiod spaces of irregular shape and very low electron density (Giese et al., 1992; Fig. 2B). In some sheaths, a collapsed, single-stranded intraperiod line was visible 

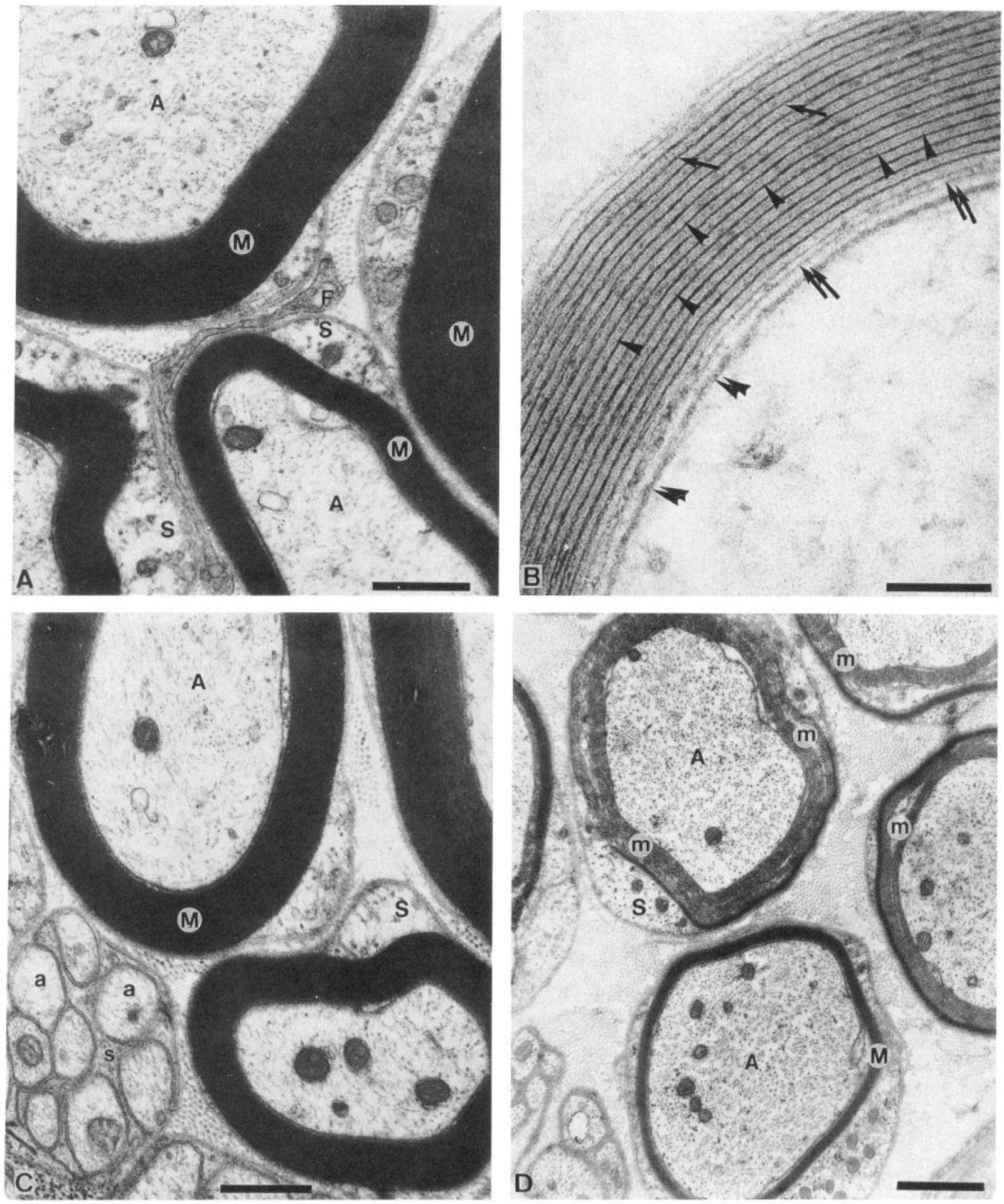

Figure 1. Electron micrographs of cross-sections of pectineus $(A, B$, and $D)$ and sciatic $(C)$ nerves of wild-type $(A$ and $B)$, $\mathrm{P}^{+-} / \mathrm{MBP}^{++}(C)$, and $\mathrm{P}^{+-} / \mathrm{MBP}^{--}$mice $(D)$. A, At low magnifications myelin $(M)$ of wild-type mice appears as electron dense ring around large caliber axons $(A)$. $F$, endoneurial fibroblast; $S$, myelinating Schwann cell. $B$, At high magnifications, myelin of wild-type mice appears in a regular organization of major dense lines (arrows) and the double-stranded intraperiod lines (arrowheads). Double arrows indicate the cytoplasmic Schwann cell collar around the myelinated axon, double arrowheads the axolemma. $C$, Myelin sheaths $(M)$ of $\mathrm{P}^{+-} / \mathrm{MBP}^{++}$mice are not different from those of wild-type mice (compare to $A$ ). A, myelinated axon; $a$, unmyelinated axon; $S$, myelinating Schwann cell; $s$, nonmyelinating Schwann cell. $D$, Axons with compacted myelin $(M)$ as well as axons surrounded by extended uncompacted aspects $(m)$ are visible. Note that the uncompacted aspects are more adjacent to the axon and that the thickness of compacted myelin is reduced relative to axonal diameter. $A$, myelinated axon; $S$, myelinating Schwann cell. Scale bars: $1 \mu \mathrm{m}$ in $A, C$, and $D ; 0.1 \mu \mathrm{m}$ in $B$. 
Table 1. Characterization of axon-Schwann cell units in pectineus nerves of wild-type mice and of several combinations of mutant alleles of $\mathrm{PO}$ and MBP

\begin{tabular}{|c|c|c|c|}
\hline & Description & $\begin{array}{l}\text { Axon } \\
\text { diameter } \\
(\mu \mathrm{m})\end{array}$ & $\begin{array}{l}\text { Axon-fiber } \\
\text { ratio }\end{array}$ \\
\hline $\mathrm{PO}^{++} / \mathrm{MBP}^{++}$ & Myelin of normal compaction & $2.99 \pm 0.41$ & $0.71 \pm 0.01$ \\
\hline $\mathrm{P}^{++} / \mathrm{MBP}^{--}$ & Myelin of normal compaction & $3.08 \pm 0.29$ & $0.66 \pm 0.02 *$ \\
\hline $\mathrm{P0}^{+-} / \mathrm{MBP}^{++}$ & Myelin of normal compaction & $2.89 \pm 0.36$ & $0.72 \pm 0.02$ \\
\hline $\mathrm{P}^{+-} / \mathrm{MPB}^{--}$ & $\begin{array}{l}\text { Myelin of normal compaction, } \\
\text { frequently interrupted by } \\
\text { noncompacted parts; reduced myelin } \\
\text { thickness }\end{array}$ & $2.93 \pm 0.35$ & $0.81 \pm 0.02 *$ \\
\hline $\mathrm{P}^{--} / \mathrm{MBP}^{++}$ & $\begin{array}{l}\text { Severe hypomyelination; } 62 \% \text { of all } \\
\text { Schwann cells form major dense } \\
\text { lines, but show predominantly poor } \\
\text { extracellular compaction; } 17 \% \text { are } \\
\text { entirely uncompacted; } 21 \% \text { do not } \\
\text { form spirals around axons }\end{array}$ & $2.18 \pm 0.19^{*}$ & \\
\hline $\mathrm{P}^{--} / \mathrm{MBP}^{--}$ & $\begin{array}{l}\text { Severe hypomyelination; no formation } \\
\text { of major dense lines; } 84 \% \text { of all } \\
\text { Schwann cells form entirely } \\
\text { uncompacted spirals around axons; } \\
16 \% \text { do not form spirals around } \\
\text { axons }\end{array}$ & $2.11 \pm 0.37^{*}$ & \\
\hline
\end{tabular}

* Values are significantly different from corresponding values of wild-type $\left(\mathrm{P0}^{+*} / \mathrm{MBP}^{*+}\right)$ mice.

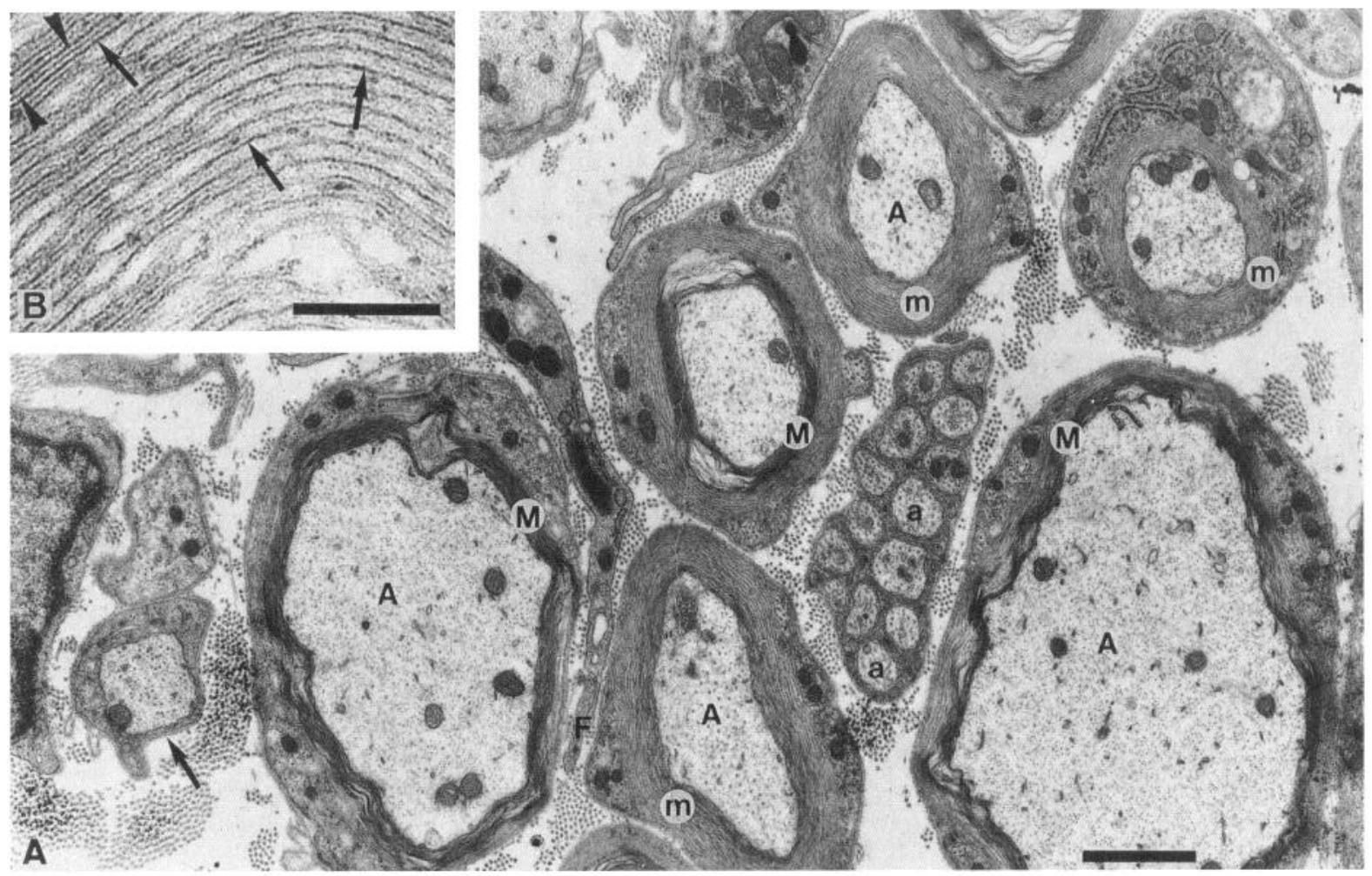

Figure 2. Electron micrographs of cross-sections of pectineus nerves of $\mathrm{P0}^{--} / \mathrm{MBP}^{++}$mice. $A$. At low magnifications, myelin-like sheaths with major dense lines $(M)$ appear more electron dense than sheaths consisting of completely uncompacted Schwann cell loops $(m)$. Note axon-Schwann cell unit without spiralling Schwann cell loops around the axon (arrow). $A$, axons surrounded by myelin-like sheaths; $a$, nonmyelinated axons; $F$, endoneurial fibroblast. B. High magnification of a myelin-like sheath containing major dense lines. In some aspects, intraperiod lines are missing, in others, single-stranded intraperiod lines of abnormally high electron density (arrowheads) are detectable. Arrows point to major dense lines. Scale bars: $1 \mu \mathrm{m}$ in $A ; 0.1 \mu \mathrm{m}$ in $B$. 

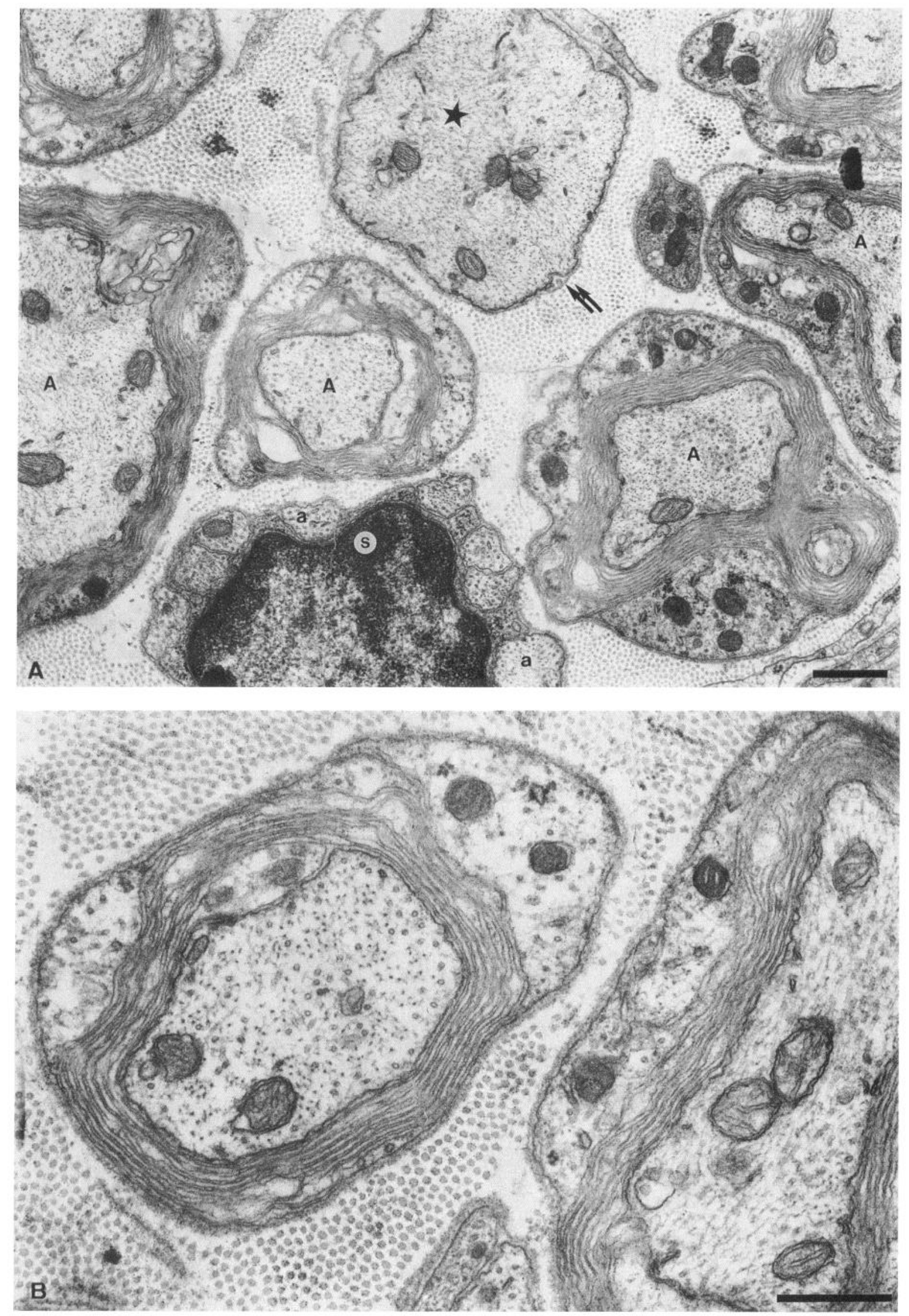
in addition to the major dense line, particularly at the more outer, abaxonal parts of major dense line-containing loops; such abnormally compacted parts had a reduced myelin periodicity (Fig. $2 B$ ). Normal myelin periodicity with a double-stranded intraperiod line was rarely seen (not shown). Of the Schwann cells having acquired a $1: 1$ ratio with axons, about $62 \%(61.8 \pm 5.3 \%$; Table 1) belonged to this group and ensheathed axons of various sizes. The second calegory comprises Schwann cells with several uncompacted loops without major dense lines (Fig. 2A) and represented only about $17 \%(16.7 \pm 2.4 \%$; Table 1$)$ of all Schwann cells having established a 1:1 ratio with axons. These Schwann cells were predominantly associated with axons of smaller diameter (Fig. 2A). The third category consists of Schwann cells without spiralling loops (Fig. $2 A$ ) and represented about $21 \%$ (21.4 $\pm 3.4 \%$; Table 1$)$ of all the Schwann cells having established a $1: 1$ ratio with axons. As in the second category, most of these Schwann cells were associated with smaller caliber axons. A common feature was the presence of myelin debris in Schwann cells, particularly in the first and the second categories (not shown, see Giese et al., 1992). Macrophages were frequently seen in the endoneurium.

In comparison to the wild-type mice, axons having achieved a 1:1 ratio with Schwann cells were reduced in caliber by about $25 \%(2.18 \perp 0.19 \mu \mathrm{m}, p \leq 0.03$; Table 1$)$. Axon-fiber ratios were not determined, since aspects containing major dense lines very rarely occupied the entire width of the myelin-like sheath (less than 1\%).

\section{$P O^{--} / M B P-($ double mutant $)$}

The behavioral phenotype of these mice was generally very similar to that of shiverer mice (P0'/MBP ). In most cases, the double mutants were smaller and weaker than shiverer mutants and had a strongly reduced life span (5-6 weeks in comparison to 3-4 months in the case of shiverer mutants). The behavioral features typical for the $\mathrm{P}^{--} / \mathrm{MBP}^{++}$mice were difficult to detect, most probably due to the predominant shiverer phenotype superimposed on the more subtle features of $\mathrm{PO}$ knock-out mice. The peripheral nerves of all four mice investigated were always severely hypomyelinated (Fig. 3A). A typical feature was the complete absence of major dense lines in the vast majority of Schwann cells forming myelin-like sheaths (Fig. 3A,B). The myelin-like sheaths thus resembled those of the second category of $\mathrm{PO}^{--} \mathrm{MBP}^{++}$mice, but contained fewer turns around the axon. Additionally, the inner lips of the Schwann cells usually appeared much more voluminous than in the other mutants (Fig. $3 B$ ). Very often, the myelin-like sheaths looked disorganized (Fig. 3A) and myelin-like structures were frequently found in phagocytotic vacuoles of the Schwann cells and of the frequent macrophages detectable in the endoneurium. Schwann cells were frequently found surrounded by a duplicated basal lamina, which is a probable indicator for de- and remyelination (not shown). In some rare cases, Schwann cells (less than 10 in each of the 4 animals investigated) were detected with a few turns containing major dense lines (not shown). These Schwann cells were only found in the sciatic and quadriceps muscle nerves, but nev- er in the pectineus muscle and femoral cutaneous nerve. Occasionally, short single-stranded intraperiod lines of abnormally high density were found. In the pectineus nerve. $16.2 \%$ $( \pm 1.8 \%)$ of the Schwann cells having established a $1: 1$ ratio with axons had only formed a single loop around the axon or had retracted from the axon living solely a basal lamina (Fig. $3 A$ ). Axonal diameters were reduced by about $30 \%$ in comparison to wild-type mice $(2.11 \pm 0.37 \mu \mathrm{m} ; p \leq 0.05$ : Table 1$)$.

\section{Discussion}

$P O$ and $M B P$ contribute to the formation of the major dense line in peripheral nerve myelin

The observation that Schwann cells deficient for PO, but expressing MBP, are able to form a myelin-like structure with a major dense line argues in favor of the possibility that MBP is involved in the intracellular compaction of peripheral nerve myelin (Giese et al., 1992; this study). Conversely, in the absence of MBP, PO alone appears to be able to form the major dense line in shiverer mice where the molecule is amply expressed (Kirschner and Ganser, 1980; Inouye et al., 1985; M. H. Mohajeri and R. Martini, unpublished observations). Investigations of mice with the $\mathrm{PO}^{+-} / \mathrm{MBP}$ - genotype extend these findings, showing that in the absence of MBP even half the dose of $\mathrm{P} 0$ is sufficient for major dense line formation. Alternatively, it is possible that in $\mathrm{P}^{+-} / \mathrm{MBP}^{-\cdot}$ mice other molecules of equivalent functions are upregulated and partially compensate for MBP and $P 0$. However, the fact that the absence of both myelin components in the double mutants (P0/MBP ) leads to the almost complete loss of major dense lines rather argues against a substantial implication of other molecules and strengthens our view that P0 and MBP can play very similar roles in the formation of major dense lines. That MBP and the intracellular domain of $\mathrm{PO}$ can fulfill similar functions would he plausible, since both molecules contain many basic amino acid residues that have been proposed to interact with the phospholipids of the opposing cytoplasmic faces of Schwann cell membranes (Cheifetz and Moscarello, 1985; Ding and Brunden, 1994). Since MBP is devoid of an extracellular domain (Lemke, 1988, for review), it is not surprising that it cannot replace the cell surface-related functions of $\mathrm{PO}$ relating to compaction of the opposing extracellular faces (Giese et al., 1992; this study).

\section{MBP may be important for stabilizing peripheral nerve myelin}

The finding that peripheral myelin is almost normal and shows well-formed major dense lines in shiverer mice raises the question as to the functional impact of MBP in peripheral nerve myelin. One could arguc that MBP is only a minor component of peripheral nerve myelin, accounting for only $5-15 \%$ of myelin proteins, whereas in the CNS it accounts for $30-40 \%$ of myelin proteins and is pivotal for myelin formation (Readhead et al., 1987; Katsuki et al., 1988; Lemke, 1988, for review). In the peripheral nerve, MBP is expressed significantly later than $\mathrm{P} 0$, that is, when five to eight lamellae of compacted myelin have been formed, whereas $P O$ is already detectable when the 1:1 ratio has been established (Hahn et al., 1987; Martini et al.,

Figure 3. Electron micrographs of cross-sections of pectineus nerves of $\mathrm{P}^{--} / \mathrm{MBP}^{-}$mice. A. At low magnitications, myelin-like sheaths are completely uncompacted. Asterisks most probably indicates a larger caliber axon without an enveloping Schwann cell; the basal lamina (double arrow) indicates the former presence of a Schwann cell. A, axons surrounded by myelin-like sheaths; $a$, nonmyelinated axons; $s$, nonmyelinating Schwann cell. $B$, At high magnifications, typical myelin-like sheaths with Schwann cell processes with cytoplasm and without major dense lines are visible. Note swollen inner lip of the turning Schwann cell process. Scale bars: $1 \mu \mathrm{m}$ in $A ; 0.3 \mu \mathrm{m}$ in $B$. 
1988). With half of the dose of $\mathrm{PO}$ in $\mathrm{PO}^{+} / \mathrm{MBP}^{--}$mice, compaction occurs at the outer myelin lamellae, which are, in extrapolation of an in vitro model (Bunge et al., 1989), the initially formed ones, whereas the inner, later formed myelin lamellae, remain uncompacted. In $\mathrm{P}\left(\right.$-deficient mice $\left(\mathrm{PO} / \mathrm{MBP}^{++}\right)$, major dense lines are found at the inner, that is, later-formed aspects of the sheath, possibly reflecting the late onset of MBP expression (see above). These observations suggest that $\mathrm{PO}$ is important for the early formation of the major dense line, whereas MBP becomes important later for stabilization and maintenance of the major dense line. It is noteworthy in this context that in 4-weekold shiverer mice, peripheral myelin is not reduced in thickness, while a mild hypomyelination has been reported in peripheral nerves of a 66-d-old shiverer mouse and in myelinating Schwann cells of shiverer genotype in 1-year-old shiverer/wildtype chimeras (Peterson and Bray, 1984). It would thus be interesting to investigate whether the age-dependent hypomyelination in Schwann cells of shiverer genotype results from degenerative events triggered by the instability of the major dense line.

\section{$P()$ and $M B P$ determine mvelin thickness}

Myelin sheaths of $\mathrm{P}^{++} / \mathrm{MBP}$ (shiverer) mice are not reduced in thickness, whereas myelin sheaths of $\mathrm{P}^{+} / \mathrm{MBP}^{--}$mice were always too thin relative to the axonal diameter. This observation implies that, when myelin forming Schwann cells are confronted with restricted resources, as, for instance, lack of MBP, myelin thickness strongly depends on the degree of $\mathrm{PO}$ expression. On the other hand, MBP becomes a crucial determinant when only half of the dose of $\mathrm{P} 0$ is available, since $\mathrm{P}^{+-} / \mathrm{MBP}^{++}$mice, but not $\mathrm{PO}^{+-} / \mathrm{MBP}$ micc, form myclin of normal thickness. This interpretation is in agreement with observations made in the CNS showing that myelin thickness depends on the degree of transgenic expression of MBP (Shine et al., 1992). It is therefore conceivable that myelin thickness is-either directly or indirectly--determined by the levels of PO and MBP that a Schwann cell synthesizes. The observation that Schwann cells forming thick myelin sheaths around larger caliber axons express more P()-specific mRNA than Schwann cells forming thin myelin sheaths around smaller axons are in agreement with this hypothesis (Griffiths et al., 1991). It is, however, possible that reduction in thickness of myelin sheaths in $\mathrm{PO}^{+} / \mathrm{MBP}^{--}$mice is the result of a partial degeneration of myelin due to reduced stability rather than to reduced ability of Schwann cells to form myelin of the correct thickness. This possibility is based on the observation that macrophages are detectable in the endoneurium of $\mathrm{PO}^{+-}$MBP mice. Studies on the development of myelin sheaths in these mice will be necessary to resolve this question.

\section{Normal axon caliber is compatible with abnormal myelin}

We have shown that axonal diameters are significantly reduced in $\mathrm{P} 0$-deficient $(\mathrm{P})^{-} / \mathrm{MBP}^{++}$) and $\left.\mathrm{P}\right)^{-} / \mathrm{MBP}^{--}$mice. These observations could be taken as further examples for the concept that glial cells can determine certain properties of axons. For instance, Schwann cells and oligodendrocytes influence the diameter of neurites when allowed to form myelin in vitro (Windebank et al., 1985). In rat optic nerve and tract, diameters of axons were strongly reduced at sites where oligodendrocytes had been ablated by $x$-ray irradiation, but were of normal size where oligodendrocytes had been allowed to survive (Colello et al., 1994). Similarly, when the hypomyelinating peripheral nerves of Trembler mice were transplanted into peripheral nerves of wild-type mice, the regrown axons of wild-type mice were significantly reduced in diameter in the implant, but regained their normal size when entering the distal stumps of the wild-type nerve (Aguayo et al., 1977). In such implants, Schwann cells of Trembler mice locally affected neurofilament phosphorylation and slow axonal transport (de Waegh and Brady, 1990, 1991; de Waegh et al., 1992). In apparent contradiction to these findings, axonal diametcrs in pcripheral nerves of $\mathrm{P} 0^{+} / \mathrm{MBP}$ mice were not reduced, although myelin was too thin for the corresponding axonal size and even uncompacted at its axonrelated aspects. This finding modifies the general view that formation of normal myelin is a crucial requirement for axons to reach their normal calibers. Furthermore, the expression of myelin-specific molecules, which may convey caliber-determining signals to the axorl, do not appear to be strictly dependent on a normal Schwann cell phenotype.

\section{Concluding remarks}

We have shown that both $\mathrm{P}(0)$ and MBP contribute to the formation of the major dense line in peripheral nerve myelin. That different molecules can fulfill similar or partially interchangeable; that is, overlapping functions appears to be a widespread phenomenon occurring in both vertebrates (see, e.g., Condie and Capecchi, 1994; this study) and invertebrates (see, e.g., Elkins et al., 1990), and is important in the interpretation of phenotypes of knock-out mutants that are less dramatic than one would expect from other experimental paradigms (see, e.g., Soriano et al., 1991; Donehower et al., 1992; Saga et al., 1992; Shull et al., 1992; Masu et al., 1993; Cremer et al., 1994; Crowley et al.. 1994; Jones et al., 1994; Montag et al., 1994, see also Erickson et al., 1993, and Strohman, 1994, for reviews). Thus, the search for possible similarly acting or even compensatory molecules followed by the inactivation of such molecules by generating double knock-out mutants will hopefully guide to a better understanding of the functional roles of individual molecules. With respect to the elucidation of the functional roles of recognition molecules, the axon-myelin unit appears to be a particularly favorable model, since it is a relatively simply organized structure comprising only two interacting cell partners and many of the putative compensatory molccules are known.

\section{References}

Aguayo AJ, Attiwell M, Trecarten J, Perkins S, Bray GM (1977) Abnormal myelination in transplanted trembler mouse Schwann cells Nature. 265:73-74

Bunge RP, Bunge MB, Bates M (1989) Movements of the Schwann cell nucleus implicate progression of the inner (axon-related) Schwann cell process during myelination. J Cell Biol 109:273-284

Cheifetz S, Moscarello MA (1985) Effect of bovine basic protein charge microheterogeneity on protein-induced aggregation of unilamellar vesicles containing a mixture of acidic and neutral phospholipids. Biochemistry 24:1909-1914.

Colello R.I, Pott U, Schwab ME (1994) The role of oligodendrocytes and myelin on axon maturation in the developing rat retinofugal pathway. J Neurosci 14:2594-2605.

Condie BG, Capecchi MR (1994) Mice with targeted disruptions in the paralogous genes hoxa- 3 and hoxd -3 reveal synergistic interactions. Nature 370:304-307.

Cremer H, Lange R, Christoph A, Plomann M, Vopper G. Roes J, Brown R, Baldwin S, Kraemer P, Scheff S, Barthels D, Rajewsky K, Wille W (1994) Inactivation of the N-CAM gene in mice results in size reduction of the olfactory bulb and deficits in spatial learning. Nature 367:455-459.

Crowley C, Spencer SD, Nishimura MC, Chen KS, Pitts-Meek S, Armanini MP, Ling LH, McMahon SB, Shelton DL, Levinson AD. Phillips HS (1994) Mice lacking nerve growth factor display perinatal 
loss of sensory and sympathetic neurons yet develop basal forebrain cholinergic neurons. Cell 76:1001-1011.

de Waegh S, Brady ST (1990) Altered slow axonal transport and regeneration in a myelin-deficient mutant mouse: the trembler as an in vivo model for Schwann cell-axon interactions. J Neurosci 10:18551865.

de Waegh SM, Brady SI (1991) Local control of axonal properties by Schwann cells: neurofilaments and axonal transport in homologous and heterologous nerve grafts. J Neurosci Res 30:201-212.

de Waegh SM, Lee VM-Y, Brady ST (1992) Local modulation of neurofilament phosphorylation axonal caliber and slow axonal transport by myelinating Schwann cells. Cell 68:45I-463.

Ding Y, Brunden K R (1994) The cytoplasmic domain of myelin protein $\mathrm{PO}$ interacts with negatively charged phospholipid bilayers. J Biol Chem 269: 10764-10770.

Donehower LA, Harvey M, Slagle BL, Mcarthur MJ, Montgomery CA Jr, Butel JS, Bradley A (1992) Mice deficient for p53 are developmentally normal but susceptible to spontaneous tumors. Nature 356: 215-221.

D'Urso D, Brophy PJ, Staugaitis SM, Gillespie CS, Frey AB, Stempak JG, Colman DR (1990) Protein zero of peripheral nerve myelin: biosynthesis membrane insertion and evidence for homotypic interaction. Neuron 2:449-460.

Elkins T, Zinn K, McAllister L, Hoffmann FM, Goodman CS (1990) Genetic analysis of a Drosophila neural cell adhesion molecule: interaction of fasciclin 1 and abelson tyrosine kinase mutations. Cell 60:565-575.

Erickson HP (1993) Gene knockouts of c-src transforming growth factor $\beta 1$ and tenascin suggest superfluous nonfunctional expression of proteins. J Cell Biol 120:1079-1081.

Filbin MT, Walsh FS, Trapp BD, Pizzey JA, Tennekoon GI (1990) Role of myelin P0 protein as a homophilic adhesion molecule. Nature 344: $871-872$.

Friede RL (1972) Control of myelin formation by axon caliber (with a model of the control mechanism). J Comp Neurol 144:233-252.

Giese KP, Martini R, Lemke G, Soriano P, Schachner M (1992) Mouse PO gene disruption leads to hypomyelination abnormal expression of recognition molecules and degeneration of myelin and axons. Cell $71: 565-576$.

Griffiths IR. McCulloch MC, Barrie JA, Kyriakides E (1991) Expression of P0 mRNA in myelinating Schwann cells is related to fibre size. J Neurocytol 20:396-403.

Hahn AF, Whitaker JN, Kachar B, Webster HdeF (1987) P2, P1 and P0 myelin protein expression in developing rat sixth nerve: a quantitative immunocytochemical study. J Comp Neurol 260:501-512.

Hogan EL, Greenfield S (1984) Animal models of genetic disorders of myelin. In: Myelin (Morell P, ed), pp 489-534. New York: Plenum.

Inouye H, Ganser AL, Kirschner D $\Lambda$ (1985) Shiverer and normal peripheral myelin compared: basic protein localization membrane interactions and lipid composition. J Neurochem 45:1911-1922.

Jones KR, Farinas I, Backus C, Reichardt LF (1994) Targeted disruption of the BDNF gene perturbs brain and sensory neuron development but not motor neuron development. Cell 76:989-999.

Katsuki M, Sato M, Kimura M, Yokoyama M, Kobayashi K, Nomura $\mathrm{T}$ (1988) Conversion of normal behavior of shiverer by myelin basic protein antisense cDNA in transgenic mice. Science 241:593-595.

Kirschner DA, Ganser AL (1980) Compact myelin exists in the ab- sence of basic protein in the shiverer mutant mouse. Nature 283:207210.

Lemke G (1986) Molecular biology of the major myelin genes. Trends Neurosci 9:266-270

Lemke $G$ (1988) Unwrapping the genes of myelin. Neuron 1:535-543

Lemke $G$ (1993) The molecular genetics of myelination: an update. Glia 7:263-271.

Martini R, Bollensen E, Schachner M (1988) Immunocytological localization of the major peripheral nervous system glycoprotein P0 and the L2/HNK-I and L3 carbohydrate structures in developing and adult mouse sciatic nerve. Dev Biol 129:330-3.38.

Masu Y, Wolf E, Holtmann B, Sendtner M, Brem G, Thoenen H (1993) Disruption of the CNTF gene results in motor neuron degeneration. Nature 365:27-32.

Montag D, Giese KP, Bartsch U, Martini R, Lang Y, Blüthmann H. Karthigasan J, Kirschner DA, Wintergerst ES, Nave K-A, Zielasek J, Toyka KV, Lipp H-P, Schachner M (1994) Mice deficient for the myelin-associated glycoprotein show subtle abnormalities in myelin. Neuron 13:229-246.

Peterson AC, Bray GM (1984) Hypomyelination in the peripheral nervous system of shiverer mice and in shiverer $\leftrightarrow$ normal chimera. J comp Neurol 227:348-356

Privat A, Jacque C, Bourre JM, Dupouey P, Baumann N (1979) Absence of the major dense line in the myelin of the mutant mouse 'shiverer.' Neurosci Lett 12:107-112.

Readhead C, Popko B, Takahashi N, Shine HD. Saavedra RA. Sidman RL, Hood L (1987) Expression of a myelin basic protein gene in transgenic shiverer mice: correction of the dysmyelinating phenotype. Cell 48:703-712.

Roach A, Boylan K, Horvath S, Prusiner SB, Hood LE (1983) Characterization of cloned $\mathrm{cDNA}$ representing rat myelin basic protein: absence of expression in brain of shiverer mutant mice. Cell 34:799806.

Rosenbluth J (1980a) Peripheral myelin in the mouse mutant shiverer. J Comp Neurol 193:729-739.

Rosenbluth J (1980b) Central myelin in the mouse mutant shiverer. J Comp Neurol 194:639-648.

Saga Y, Yagi T, Ikawa Y, Sakakura T, Aizawa S (1992) Mice develop normally without tenascin. Genes Dev 6:1821-1831.

Schneider-Schaulies J, von Brunn A, Schachner M (1990) Recombinant peripheral myclin protein PO confers both adhesion and ncurite outgrowth-promoting properties. J Neurosci Res 27:286-297.

Shine HD, Readhead C, Popko B, Hood L, Sidman RL (1992) Morphometric analysis of nomal mulant and transgentic CNS: correlation of myelin basic protein expression to myelinogenesis. J Neurochem $58: 342-349$.

Shull MM, Ormsby I, Kier AB, Pawlowski F, Diebold RJ, Yin M, Allen R, Sidman C, Proetzel G, Calvin D, Annunziata N, Doetschman T (1992) Targeted disruption of the mouse transforming growth factor$\beta 1$ gene results in multifocal inflammatory disease. Nature $359: 693$ 699.

Soriano P, Montgomery C, Geske R, Bradley A (1991) Targeted disruption of the of the c-src proto-oncogene leads to osteopetrosis in mice. Cell 64:693-702.

Strohman R (1994) Epigenesis: the missing beat in biotechnology? Biotechnology 1:156-163.

Windebank AJ, Wood P, Bunge RP, Dyck PJ (1985) Myelination determines the caliber of dorsal root ganglions in culture. J Neurosci $5: 1563-1569$. 